\title{
Extrafine inhaled corticosteroid therapy in the control of asthma
}

\author{
This article was published in the following Dove Press journal: \\ Journal of Asthma and Allergy \\ 5 June 2013 \\ Number of times this article has been viewed
}

\section{István Ivancsó \\ Renáta Böcskei \\ Veronika Müller \\ Lilla Tamási \\ Department of Pulmonology, Semmelweis University, Budapest, Hungary}

Correspondence: Lilla Tamási Semmelweis University, Department of Pulmonology, Diós árok I/c, Budapest II25, Hungary,

Tel +36 I355 9733

Fax +36 I2I 42498

Email tamasi@pulm.sote.hu

\begin{abstract}
Small airways disease plays an important role in the pathogenesis of asthma, but assessment of small airways impairment is not easy in everyday clinical practice. The small airways can be examined by several invasive and noninvasive methods, most of which can at present be used only in the experimental setting. Inhalers providing extrafine inhaled corticosteroid particle sizes may achieve sufficient deposition in the peripheral airways. Many studies have reported the beneficial effects of extrafine inhaled corticosteroids on inflammation, ie, on dysfunction in both the central and distal airways in asthmatics, and there are some data on asthma phenotypes in which the small airways seem to be affected more than in other phenotypes, including nocturnal asthma, severe steroid-dependent or difficult-to-treat asthma, asthma complicated by smoking, elderly asthmatic patients and/or patients with fixed airflow obstruction, and asthmatic children. The relevant randomized controlled clinical trials indicate that the efficacy of extrafine and nonextrafine inhaled corticosteroid formulations is similar in terms of primary endpoints, but there are certain clinically important endpoints for which the extrafine formulations show additional benefits.
\end{abstract}

Keywords: small airways, inflammation, dysfunction, noninvasive evaluation methods, peripheral deposition

\section{Introduction}

Asthma has several phenotypes and endotypes with different underlying mechanisms, ${ }^{1,2}$ and chronic airways inflammation plays a principal role in airways narrowing, hyperreactivity, and remodeling in all of these conditions. Inhaled corticosteroids (ICS) aim to treat this inflammation locally, to improve asthma control, and to decrease mortality from the disease. Hence, ICS constitute the primary maintenance therapy for patients with persistent asthma. ${ }^{3}$ Even so, there are some patients who remain uncontrolled despite therapy, ${ }^{4-6}$ and progressive asthma-related worsening of lung function can occur, regardless of the treatment used. ${ }^{4,7,8}$ The most recent asthma guidelines recommend treatment according to control, but real-life studies show that optimal control is not reached at all in many patients. ${ }^{9-11}$ It has been suggested that one reason for therapeutic failure may be impairment of the small airways. ${ }^{12,13}$

Small airways are $\leq 2 \mathrm{~mm}$ in diameter, and are also called peripheral or distal airways according to their location. Inflammation and structural changes are observed in the distal airways in patients with asthma. These changes may be more marked than those in the central airways, ${ }^{12}$ and the lung parenchyma may also be affected beyond the airway wall. ${ }^{14,15}$ Given that the total volume and combined surface area of the peripheral airways are much greater than those of the large airways,${ }^{16}$ it has been suggested that 
abnormalities occurring in the small airways may be more important in the pathophysiology of asthma than was once believed. ${ }^{17-19}$ Recently developed ICS formulations provide extrafine particle sizes for inhalation, which can penetrate more effectively into the distal lung. The aim of this review is to assess the possible role of extrafine ICS preparations in anti-inflammatory maintenance therapy for asthma.

\section{Inflammation and remodeling in the small airways}

Autopsy studies have yielded surprising data regarding the role of the peripheral airways in the pathogenesis of asthma, ie, many researchers have found that the entire length of the airways is affected by pathological processes. ${ }^{15,18,20-28}$ In acute fatal asthma, there is marked goblet cell hyperplasia and intraluminal accumulation of mucus throughout the whole bronchial tree, which is particularly pronounced in the peripheral airways. ${ }^{20,21}$ Mucoinflammatory exudates occluding the lumen contain more cells in the small airways than those in the larger airways. ${ }^{21}$ Tissue taken at autopsy from asthmatic patients who died within one hour of onset of symptoms has been reported to contain infiltrates of T cells, macrophages, and eosinophils in both the large and small airways. ${ }^{22}$ In fact, several autopsy studies have shown remodeling in the small airways, which might be caused by persistent inflammation. ${ }^{18,23-27}$ Moreover, it is likely that mast cells play an important role in distal lung remodeling in patients who succumb to fatal asthma; ${ }^{15}$ at the same time, it must also be mentioned that this type of cell is also claimed to protect lung function in those with severe asthma. ${ }^{29}$

Further, inflammation and remodeling are thought to play a crucial role in bronchial hyperresponsiveness. ${ }^{23,24,30}$ Chronic inflammation disrupting the parenchyma can cause loss of alveolar attachment in the small airways, resulting in decreased elastic recoil and increased collapsibility of the small airways in fatal asthma. ${ }^{18,27,28}$ Analysis in a model of airways narrowing revealed that thickening of the airway wall, especially in the peripheral airways, is the main cause of narrowing of the airways and is attributable to smooth muscle shortening. Apart from that, wall thickening and loss of recoil are more than additive in their effects on airway responsiveness. ${ }^{24}$

Autopsy studies have been carried out primarily in subjects with acute fatal exacerbations, but data on small airways pathology can also be obtained from living asthmatics. In one study investigating surgical specimens from patients with asthma who underwent thoracic surgery, there was an increase in the numbers of T cells and total and activated eosinophils both in the large and small airways when compared with the airways of healthy controls. However, the number of activated eosinophils was greater in the small airways than in the large ones, indicating similar but more severe inflammation in the peripheral airways as compared with the central airways. ${ }^{12}$ In another study investigating the same lung specimens, the investigators found increased interleukin (IL)-5 and IL-4 mRNA-positive cells in the large and small airways and lung parenchyma of asthmatics, but expression of IL-5 mRNA was greater in the small airways than in the large airways. ${ }^{31}$ The authors observed increased eosinophil-associated chemokines, including eotaxin and monocyte chemotactic protein-4 mRNA expression, in both the large and small airways of asthmatics compared with nonasthmatics, and showed that expression of eotaxin mRNA correlated with the number of eosinophils present in the airways of asthmatic subjects. ${ }^{32}$ Given that traditional ICS reach mainly the larger airways, more severe inflammation observed in the small airways may be caused by suppressed inflammation in the large but not small airways due to regular ICS therapy. ${ }^{33,34}$

Investigation of transbronchial biopsy specimens provides further evidence about the role of small airways pathology in asthma. An interesting study was carried out by Kraft et al, who performed endobronchial and transbronchial biopsies in patients with nocturnal asthma and in those with non-nocturnal asthma at $4 \mathrm{pm}$ and $4 \mathrm{am}$. Patients with nocturnal asthma had increased numbers of eosinophils in their distal lung parenchyma at night compared with patients with non-nocturnal asthma, but there was no difference in numbers of eosinophils in the proximal airways between the two groups. ${ }^{14}$ Other researchers analyzed bronchoalveolar lavage specimens from severely symptomatic, high-dose, oral glucocorticoid-dependent asthmatics as well as endobronchial and transbronchial biopsy specimens, and despite high-dose steroid treatment, they found higher numbers of neutrophils and elevated levels of eicosanoid mediators in specimens from these patients compared with those from mild-to-moderate asthmatics or healthy controls, ${ }^{35}$ suggesting persistent proximal and distal airways inflammation in severe asthmatics regardless of use of systemic corticosteroids. Furthermore, other studies investigating bronchial and transbronchial biopsies from severe asthmatics found that severe patients have increased parenchymal infiltration also of mast cells as compared with their large airways. ${ }^{29,36}$ The smaller number of mast cells in the large airways may be due to treatment with corticosteroids. ${ }^{33}$

In a recent review, Contoli et al evaluated data on small airway abnormalities in severe asthma, asthma in smokers, 
and asthma in the elderly. ${ }^{37}$ With ageing and/or a long duration of disease, the elastic fibers in the small airways degenerate, resulting in increased collapsibility and air trapping, with additional development of fixed airflow obstruction over time. ${ }^{38}$ Smoking asthmatics are characterized by a faster decline in lung function, frequent exacerbations, worse asthma control, enhanced remodeling, ${ }^{39}$ and impaired sensitivity to both inhaled and oral corticosteroids. ${ }^{40,41}$ Contoli et al concluded that small airways involvement plays a major role in the pathogenesis of these phenotypes. ${ }^{37}$ It follows from this that clinical trials of pharmaceuticals which are able to penetrate the distal segment are needed in these subgroups. Given that it is still an open question as to whether small airways are affected in all asthmatics or only in some phenotypes, further studies seem necessary to phenotype patients according to small airway abnormalities. ${ }^{37}$ The abovementioned histological evidence regarding small airway pathology is summarized in Table 1.

\section{Evaluation of small airways function in obstructive lung disease Measurements of lung function}

Using retrograde catheter examination in animal models, low resistance values have been found in the lower airways, which have been demonstrated to contribute less than $10 \%$ to total lung resistance. ${ }^{42}$ This can be explained by the fact that the total volume of the airways increases with the number of generations of the bronchial tree. ${ }^{16}$ Therefore, the small airways normally contribute very little to parameters obtained by standard lung function measurements, which are more reflective of conditions in the large airways; hence asthmatic patients with normal or near normal forced expiratory volume in one second $\left(\mathrm{FEV}_{1}\right)$ values can still have small airways dysfunction, as confirmed by a study using invasive measurements with wedged bronchoscopy. ${ }^{19}$ Moreover, in another invasive study using endobronchial catheterization, researchers demonstrated an increased contribution of the small airways to total lung resistance in moderate to severe asthmatics with airflow obstruction and in patients with chronic bronchitis or emphysema as compared with mild asthmatics without airflow obstruction and healthy controls. This suggests that the peripheral airways are the predominant site of chronic airflow obstruction. ${ }^{17}$ Because traditional spirometric parameters mostly fail to detect small airways impairment, there is a need for other noninvasive methods by which to investigate lung function. The lung function parameter most commonly considered to reflect small airways obstruction is forced expiratory flow at $25 \%-75 \%$ of forced vital capacity
(FVC), ie, $\mathrm{FEF}_{25 \%-75 \%}$. Nonetheless, this parameter is highly variable in serial measurements and is influenced by both central airway obstruction and alterations in lung volume due to air trapping or bronchodilation. Further, this parameter fails to correlate with other parameters of air trapping, such as FVC or residual volume (RV)/total lung capacity (TLC) $)^{43}$ or with inflammation of the small airways, as the research on transbronchial biopsy specimens in patients with severe asthma has demonstrated. ${ }^{44}$

Air trapping frequently results from small airways inflammation, reflects hyperinflation, and causes elevated RV. The $\mathrm{RV} / \mathrm{TLC}$ ratio is a more valid parameter of small airways impairment because TLC is often increased in patients with asthma, ${ }^{45}$ and is more elevated in severe than in nonsevere asthma, so air trapping is considered a characteristic feature of the population with severe asthma. ${ }^{43}$ Decreased FVC is also related to air trapping, ${ }^{46,47}$ and FVC shows an inverse correlation with RV/TLC. ${ }^{43}$ However, this parameter alone is not sensitive enough to air trapping and assumes normal TLC, which can be elevated in obstructive diseases as a means of compensation, hence reduction in FVC should only be used as an air trapping marker in the absence of lung volume measurements.

\section{Nitric oxide}

Fractional exhaled nitric oxide has been proposed as a marker of eosinophil inflammation in asthma. The threshold level of $\geq 3 \%$ eosinophils in sputum is usually considered clinically relevant, and a threshold of $42 \mathrm{ppb}$ fractional exhaled nitric oxide value has been confirmed to distinguish between eosinophilic ( $\geq 3 \%$ ) versus noneosinophilic $(<3 \%)$ asthma with reasonable accuracy. A high dose of ICS and cigarette smoking can decrease this threshold while atopy can increase it. ${ }^{48}$ In a 5-year, prospective follow-up study of difficult-to-treat patients, it was observed that asthmatics with high total fractional exhaled nitric oxide ( $\geq 20 \mathrm{ppb}$ ) had an excessive decline in lung function as compared with patients having low fractional exhaled nitric oxide, and this relationship was even stronger in the subgroup of patients with normal baseline $\mathrm{FEV}_{1}$, suggesting that this difference was not reflecting large airways impairment but rather small airways impairment. ${ }^{8}$

However, exhaled nitric oxide without further refinement is not selective for small versus large airways, but there are methods which can discriminate between the bronchial and alveolar contribution to production of nitric oxide. ${ }^{49-52}$ A higher alveolar nitric oxide level was shown to correlate with small airways dysfunction in a subgroup 
Table I Histological evidence of small airways pathology in asthma

\begin{tabular}{|c|c|c|c|}
\hline Authors & Type of specimen & Subjects & Findings in small airways \\
\hline Hamid et al' ${ }^{12}$ & Surgically resected lungs & 6 asthma, 10 controls & $\begin{array}{l}\text { Increased T cells and eosinophils in all asthmatic airways. } \\
\text { Greater numbers of activated eosinophils in the small airways. }\end{array}$ \\
\hline Kraft et al ${ }^{14}$ & $\begin{array}{l}\text { Transbronchial biopsy } \\
\text { (proximal airway } \\
\text { endobronchial and distal } \\
\text { alveolar tissue) }\end{array}$ & $\begin{array}{l}\text { II nocturnal asthma, } \\
\text { I0 non-nocturnal asthma }\end{array}$ & $\begin{array}{l}\text { Greater number of eosinophils in nocturnal asthma alveolar } \\
\text { tissue at } 4 \text { am as compared with non-nocturnal asthma. } \\
\text { Greater number of eosinophils and macrophages in the } \\
\text { nocturnal asthma alveolar tissue at } 4 \text { am as compared with } \\
4 \mathrm{pm} \text {. Only alveolar tissue eosinophils correlated with the } \\
\text { nocturnal decrement in lung function. }\end{array}$ \\
\hline $\begin{array}{l}\text { de Magalhães } \\
\text { Simões et } \text { al }^{15}\end{array}$ & $\begin{array}{l}\text { Nasal mucosa, trachea, } \\
\text { intrapulmonary airways } \\
\text { and peribronchiolar } \\
\text { and distal parenchyma }\end{array}$ & 20 fatal asthma, 10 controls & $\begin{array}{l}\text { Higher eosinophil content in all studied areas in fatal } \\
\text { asthma. The outer wall of small membranous bronchioles } \\
\text { is the main site of inflammatory changes in fatal asthma. } \\
\text { There is a localized distribution of alveolar inflammation at } \\
\text { the peribronchiolar region for mast cells and neutrophils. }\end{array}$ \\
\hline Kuwano et al ${ }^{18}$ & $\begin{array}{l}\text { Autopsied lungs } \\
\text { Surgically } \\
\text { resected lungs }\end{array}$ & $\begin{array}{l}8 \text { fatal asthma, } \\
7 \text { nonfatal asthma, } \\
15 \text { mild COPD, I5 controls }\end{array}$ & $\begin{array}{l}\text { The membranous airways showed a gradation in wall } \\
\text { thickening in fatal asthma }>\text { nonfatal asthma }>\text { COPD }> \\
\text { control. }\end{array}$ \\
\hline Aikawa et al ${ }^{20}$ & Autopsied lungs & $\begin{array}{l}3 \text { died of severe acute asthma attack, } \\
5 \text { died of nonstatus asthmaticus, } \\
4 \text { died of nonrespiratory causes } \\
\text { (controls) }\end{array}$ & $\begin{array}{l}\text { Increased goblet percent and mucus in patients who died } \\
\text { of a severe acute asthma attack; more dominant in the } \\
\text { peripheral airways. Mucus correlated with goblet percent in } \\
\text { the peripheral airways. }\end{array}$ \\
\hline Kuyper et $\mathrm{a}^{21}$ & Autopsied lungs & 93 fatal asthma, including 19 children & $\begin{array}{l}\text { Cells made up a higher proportion of exudate in the small } \\
\text { airways. }\end{array}$ \\
\hline Faul et $\mathrm{al}^{22}$ & Autopsied lungs & 5 sudden asphyxic asthma deaths & $\begin{array}{l}\text { Both proximal and distal tissues showed infiltrates of } \mathrm{T} \\
\text { cells, macrophages, and eosinophils, with a CD8+ T cell } \\
\text { predominance; a high proportion of eosinophils were } \\
\text { activated. }\end{array}$ \\
\hline James et $\mathrm{a}^{23}$ & Autopsied lungs & I8 asthma, 23 controls & $\begin{array}{l}\text { Greater wall area (epithelium, muscle, and submucosa) both } \\
\text { in the membranous and cartilaginous airways in asthma. }\end{array}$ \\
\hline Carroll et $\mathrm{al}^{26}$ & Autopsied lungs & $\begin{array}{l}\text { II fatal asthma, } \\
\text { I } 3 \text { nonfatal asthma, } \\
\text { II controls }\end{array}$ & $\begin{array}{l}\text { Greater total and outer wall areas in the small membranous } \\
\text { bronchioles (perimeter }<2 \mathrm{~mm} \text { ) in fatal and nonfatal } \\
\text { asthma. Structural changes occur in the large and small } \\
\text { airways in fatal asthma, but predominantly in the small } \\
\text { airways in nonfatal asthma. }\end{array}$ \\
\hline $\begin{array}{l}\text { Dolhnikoff } \\
\text { et a }\left.\right|^{27}\end{array}$ & Autopsied lungs & $\begin{array}{l}24 \text { fatal asthma, } \\
\text { II controls }\end{array}$ & $\begin{array}{l}\text { Increased collagen I and decreased collagen III content } \\
\text { in the small airways, increased fibronectin and MMP-I, } \\
\text { MMP-2, and MMP-9 content at the outer area of the small } \\
\text { airways, increased MMP content in the peribronchiolar } \\
\text { parenchyma in asthmatics. }\end{array}$ \\
\hline Mauad et $\mathrm{al}^{28}$ & Autopsied lungs & $\begin{array}{l}\text { I5 fatal asthma, } \\
9 \text { controls }\end{array}$ & $\begin{array}{l}\text { Increased proportion of abnormal alveolar attachments } \\
\text { and decreased elastic fiber content in the small airways } \\
\text { adventitial layer and in the peribronchial alveoli (but not in } \\
\text { the distal alveoli) in fatal asthma. }\end{array}$ \\
\hline Balzar et $\mathrm{a}^{29}$ & $\begin{array}{l}\text { Endobronchial and } \\
\text { transbronchial/surgical } \\
\text { biopsy tissue }\end{array}$ & 20 severe asthma & $\begin{array}{l}\text { The number of inflammatory cells increased toward } \\
\text { the periphery, but the percentage of T lymphocytes, } \\
\text { eosinophils, monocytes/macrophages, and neutrophils } \\
\text { remained at a similar value or decreased from the large } \\
\text { to the small airways. In contrast, mast cell number and } \\
\text { percentage, as well as the chymase-positive phenotype } \\
\text { increased in the small airway regions. Chymase-positive } \\
\text { mast cells in the small airway/alveolar attachments lung } \\
\text { region correlated positively with lung function. }\end{array}$ \\
\hline Minshall et $\mathrm{al}^{31}$ & Surgically resected lungs & $\begin{array}{l}6 \text { asthma, } \\
10 \text { controls }\end{array}$ & $\begin{array}{l}\text { Increased IL- } 5 \text { and IL- } 4 \text { mRNA-positive cells both in } \\
\text { the large and small airways in asthmatics, but increased } \\
\text { expression of IL- } 5 \text { mRNA in the small airways as compared } \\
\text { with the large airways. }\end{array}$ \\
\hline Taha et $\mathrm{al}^{32}$ & Surgically resected lungs & $\begin{array}{l}6 \text { asthma, } \\
10 \text { controls }\end{array}$ & $\begin{array}{l}\text { Increased expression of eotaxin and monocyte chemotactic } \\
\text { protein- } 4 \text { mRNA in the large and small airways of asthmatics. }\end{array}$ \\
\hline
\end{tabular}


Table I (Continued)

\begin{tabular}{llll}
\hline Authors & Type of specimen & Subjects & Findings in small airways \\
\hline Wenzel et $\mathrm{al}^{35}$ & Bronchoalveolar lavage fluid & I4 severe, high-dose oral & Higher numbers of neutrophils and elevated levels of \\
& Endobronchial and & glucocorticoid-dependent asthma, & eicosanoid mediators in severe asthma. \\
& transbronchial biopsies & 12 moderate asthma, 6 controls & \\
Andersson & Bronchial and & I4 uncontrolled asthma, & Increased alveolar mast cell density, FcERI expression and \\
et al ${ }^{36}$ & transbronchial biopsies & 8 allergic rhinitis, 8 controls & surface-bound immunoglobulin E in asthma. \\
\hline
\end{tabular}

Abbreviations: COPD, chronic obstructive pulmonary disease; CD, cluster of differentiation; IL, interleukin; MMP, matrix metalloproteinase; FcERI, low-affinity immunoglobulin $\mathrm{E}(\lg \mathrm{E})$ receptor.

with stable asthma.$^{49}$ Further, in patients with severe asthma, strong correlations were found between alveolar nitric oxide levels and RV/TLC, functional residual capacity (FRC), the slope of the single-breath nitrogen washout curve (dN2), and closing capacity/TLC (see below). Hence, the authors concluded that alveolar nitric oxide is closely related to parameters of peripheral airway dysfunction in patients with severe asthma. ${ }^{50}$ Another study showed that patients with refractory asthma had elevated alveolar nitric oxide levels as compared with mild-to-moderate asthmatics or healthy controls and, more importantly, it was claimed that oral prednisolone caused a fall in the alveolar nitric oxide level but doubling the dose of already received nonextrafine ICS therapy did not. ${ }^{51}$ However, the limitations of these data must also be pointed out because elevated alveolar nitric oxide in these studies may reflect at least partial back-diffusion of nitric oxide from the conducting airways, so these values must be corrected. Indeed, in a more recent study, corrected alveolar nitric oxide was not elevated in treated severe asthmatics as compared with mild-to-moderate asthmatics or healthy volunteers. ${ }^{52}$

\section{High-resolution CT scanning}

High-resolution computed tomography (CT) scanning is a sensitive imaging technique which objectively shows indirect signs of small airways obstruction, such as heterogeneity in ventilation (areas of mosaic lung attenuation on inspiratory CT) and air trapping (on expiratory CT). ${ }^{53-57}$ Studies showed a higher degree of air trapping on high-resolution CT scan even in mild asthma, ${ }^{53,54}$ and more severe asthma is associated with more severe air trapping. ${ }^{55}$ Air trapping scores were also higher in mild asthmatics after metacholine challenge, but air trapping only partially disappeared after inhalation of salbutamol. Further, lung attenuation was higher in patients with asthma in this study. ${ }^{53}$ In contrast, unstable asthmatics with exacerbations had lower mean lung density and a higher relative lung area with low attenuation than controls or stable asthmatics, which was at least partially reversible using systemic glucocorticoid therapy and in parallel with improvements in $\mathrm{FEV}_{1}$ and $\mathrm{RV}^{56}$ Moreover, in stable patients, the percentage of lung field occupied by low attenuation areas on expiratory scan correlated negatively with $\mathrm{FEV}_{1} /$ FVC and with indices of peripheral airflow obstruction, such as $\mathrm{FEF}_{25 \%-75 \%{ }^{\circ}}{ }^{57}$ Systemically administered drugs reach the small airways via the circulation; 4 weeks of treatment with oral montelukast in fact resulted in less metacholine-induced air-trapping on high-resolution CT as well as in improved quality of life in mild-to-moderate asthmatics. ${ }^{58}$

\section{Single-breath and multiple-breath washout tests}

Dysfunction of the small airways can be evaluated by singlebreath washout tests and more accurately by multiple-breath washout tests. ${ }^{45,59-65}$ Both techniques use endogenous or exogenous inert gases and can provide several parameters reflecting distribution of inhomogeneity in ventilation and/ or air trapping. ${ }^{60,61}$

The most widely used method is the $\mathrm{N}_{2}$ single-breath washout test. ${ }^{60}$ In this test, increased closing volume (expired volume from the start of phase IV to the end of the breath) implies airway closure at relatively high lung volumes. Indeed, closing volume has been shown to correlate with RV/TLC. ${ }^{62}$ Closing volume and closing capacity $(\mathrm{CC}=\mathrm{CV}+\mathrm{RV})$ were increased in patients with difficult-to-control asthma as compared with a group with equally severe but stable asthma even during a clinically stable period and after bronchodilation. This suggests that collapsibility of the small airways might be a risk factor for exacerbations in asthmatics. ${ }^{63}$ Similarly, another cross-sectional study of patients with variable severity of asthma but normal $\mathrm{FEV}_{1}$ showed that the closing capacity/ TLC and phase III slope of the washout curve (ie, alveolar phase; $\mathrm{S}_{\mathrm{III}}$ or dN2) was increased in asthma. Moreover, dN2 increased significantly in patients with frequent exacerbations as compared with those with rare exacerbations at steady-state after bronchodilation. Further, dN2 correlated negatively with asthma control (assessed by the Asthma Control Questionnaire) and positively with the number of exacerbations and RV/TLC. The results of this study indicate 
that an abnormal dN2 value can be associated with the need for a high daily dose of ICS. ${ }^{45}$

The multiple-breath washout test can locate the affected small airways in acinar (Sacin, index of acinar ventilation heterogeneity) and conductive (Scond, index of conductive ventilation heterogeneity) lung zones. ${ }^{59}$ Both parameters have been found to be abnormal in asthma. ${ }^{64}$ Moreover, Scond was shown to be a strong predictor of airways hyperresponsiveness in asthma, irrespective of airways inflammation. ${ }^{65}$ Single-breath and multiple-breath washout tests are suitable for assessment of small airways impairment in experimental models but not in clinical settings at present.

\section{Impulse oscillometry}

Impulse oscillometry is another noninvasive technique developed to measure airway mechanics expressed by the parameters of resistance $(\mathrm{R})$ and reactance $(\mathrm{X})$ at different frequencies. An important advantage of this method is that, unlike spirometry, it does not require any respiratory maneuvers but simply normal breathing while smallamplitude pressure oscillations at multiple frequencies are sent into the respiratory system and parameters are derived from the reflected signals. Therefore, it may be concluded that this method is both effort-dependent and cooperationindependent. ${ }^{52,66}$ Using this technique, it is possible to discriminate between functions of the large and small airways; small airways obstruction is sensitively detectable with increased resistance predominantly at low frequencies. ${ }^{13,66}$ Peripheral resistance (R5-R20) was observed to correlate with $\mathrm{FEF}_{25 \%-75 \%}$ and alveolar nitric oxide levels. ${ }^{52}$ Impulse oscillometry parameters are more sensitive than spirometric parameters in recognizing subtle dysfunction, as was shown in a study involving subjects with normal spirometry following the World Trade Center dust exposure ${ }^{67}$ and in other studies where asthmatic children receiving oral montelukast ${ }^{68}$ or patients with asthma or chronic obstructive pulmonary disease receiving bronchodilator pharmaceuticals were examined, ${ }^{69}$ and in yet other studies where healthy individuals were tested after exercise in the cold and at room temperature. ${ }^{70}$ Moreover, impulse oscillometry was shown to correlate better than spirometry with clinical symptoms and asthma control. ${ }^{13}$ Noninvasive investigation methods that can be used in assessment of the small airways are summarized in Table 2 .

\section{Extrafine ICS therapy for airways inflammation in asthmatics}

As seen above, there is evidence in support of inflammatory processes also occurring in the distal lung in asthma.
From this, it follows that targeting inflammation in both the central and peripheral airways may be beneficial in pharmacotherapy for asthma. Lung deposition studies show that there is an inverse correlation between the particle size of inhaled drug formulations and extent of deposition in the lung. ${ }^{71-73}$ Traditional dry powder inhalers or chlorofluorocarbon-metered dose inhaler devices generate particles with a median mass aerodynamic diameter of 2-4 $\mu \mathrm{m} .{ }^{73}$ However, newer pressurized metered dose inhalers have recently been developed using hydrofluoroalkane solution, and generate an aerosol of smaller particles with a median mass aerodynamic diameter of approximately $1 \mu^{30}$ (eg, hydrofluoroalkane-beclomethasone dipropionate, hydrofluoroalkane-beclomethasone dipropionate/ formoterol, hydrofluoroalkane-flunisolide, and hydrofluoroalkane-ciclesonide). Extrafine formulations have a lung deposition rate of $50 \%-60 \%$ and penetrate more deeply into the peripheral airways than drugs delivered via traditional inhalers. In a study comparing healthy subjects and patients with chronic obstructive pulmonary disease or asthma, deposition of hydrofluoroalkane-formoterol in the lung was shown to be independent of lung function, ${ }^{74}$ and it was also demonstrated that deposition of hydrofluoroalkanebeclomethasone dipropionate in the lung was not affected in the event of transient deterioration in $\mathrm{FEV}_{1}{ }_{1}{ }^{75}$

Hauber et al investigated the effect of hydrofluoroalkaneflunisolide on airway inflammation using transbronchial and endobronchial biopsies. They found reductions in eosinophil numbers and IL-5 and eotaxin levels both in the peripheral and central airways accompanied by an improvement in lung function after 6 weeks of treatment. However, neutrophils increased and lymphocytes remained unchanged. ${ }^{34}$ A similar study demonstrated the effect of hydrofluoroalkaneflunisolide, which caused a decrease in $\alpha$-smooth muscle actin area (a sign of airways remodeling) in the peripheral airways. This change correlated with improvement in $\mathrm{FEF}_{25 \%-75 \%}{ }^{76}$ The effect of hydrofluoroalkane- beclomethasone dipropionate on eosinophil inflammation was assessed in a long-term study, where patients receiving traditional ICS therapy (budesonide or fluticasone administered by dry powder inhaler) were switched to extrafine ICS treatment. ${ }^{77}$ On the basis of induced sputum investigations, there was a decrease in the number of patients with eosinophilic inflammation. Further, reductions in sputum eosinophil cationic protein and eotaxin were observed after 8 weeks, and their concentrations continued to decrease for one year. ${ }^{77}$ In another study, late-phase sputum eosinophil levels decreased after the introduction of treatment with extrafine ciclesonide as opposed to treatment with nonextrafine fluticasone. ${ }^{78}$ 
Table 2 Noninvasive tools suitable for assessment of small airways

\begin{tabular}{|c|c|c|c|}
\hline Method & Scope & Strengths & Weaknesses \\
\hline $\mathrm{FEF}_{25 \%-75 \%} 43,44$ & $\begin{array}{l}\text { Small airways obstruction } \\
\text { Correlates with IOS and HRCT indices }\end{array}$ & Easy to perform & $\begin{array}{l}\text { Too variable } \\
\text { Influenced by central airways } \\
\text { obstruction or lung volume alterations } \\
\text { Fails to correlate with other } \\
\text { parameters of air trapping or with } \\
\text { small airway inflammation }\end{array}$ \\
\hline $\mathrm{RV} / \mathrm{TLC}^{43,45}$ & $\begin{array}{l}\text { Air trapping } \\
\text { Elevated in asthma, particularly in severe disease }\end{array}$ & Easy to perform & Relatively time-consuming \\
\hline $\mathrm{FVC}^{43,46,47}$ & $\begin{array}{l}\text { Decreased FVC was related to air trapping; } \\
\text { FVC correlates inversely with RV/TLC }\end{array}$ & Easy to perform & $\begin{array}{l}\text { Not sensitive } \\
\text { Assumes normal TLC }\end{array}$ \\
\hline $\mathrm{CA}(\mathrm{NO})^{49-52}$ & $\begin{array}{l}\text { Ventilation heterogeneity } \\
\text { (particularly in severe and refractory asthma) } \\
\text { Correlates with RV/TLC, FRC, dN2, } \\
\text { CC/TLC, R5-R20 }\end{array}$ & Good reproducibility & $\begin{array}{l}\text { Back-diffusion of } \mathrm{NO} \text { from the } \\
\text { conducting airways } \\
\text { Corrected } \mathrm{CA}(\mathrm{NO}) \text { is not elevated } \\
\text { in treated severe asthmatics }\end{array}$ \\
\hline $\mathrm{HRCT}^{53-58,81}$ & 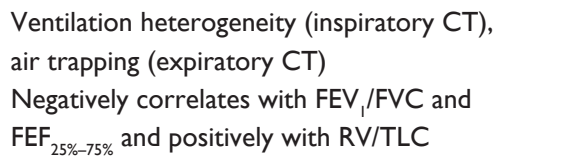 & $\begin{array}{l}\text { Sensitive } \\
\text { Good reproducibility and objective } \\
\text { if computerized and spirometrically } \\
\text { controlled }\end{array}$ & $\begin{array}{l}\text { Radiation } \\
\text { Expensive }\end{array}$ \\
\hline $\begin{array}{l}\text { SBW, MBW } \\
\text { tests }^{45,59-65}\end{array}$ & $\begin{array}{l}\text { Ventilation heterogeneity, air trapping, } \\
\text { collapsibility of small airways } \\
\mathrm{CV} \text { and dN2 correlate with RV/TLC } \\
\mathrm{dN} 2 \text { correlates with recurrent exacerbations } \\
\text { and asthma control } \\
\text { Scond predicts airway hyperresponsiveness }\end{array}$ & $\begin{array}{l}\text { Sensitive, able to detect early changes } \\
\text { in small airways } \\
\text { Good reproducibility (if computerized) }\end{array}$ & Difficult to perform \\
\hline $\operatorname{IOS}^{13,52,66-70}$ & $\begin{array}{l}\text { Airway mechanics, small airway obstruction } \\
\text { R5-R20 correlates with } \mathrm{FEF}_{25 \%-75 \%} \text { and } \mathrm{CA}(\mathrm{NO}) \\
\text { Correlates with symptoms and control } \\
\text { better than spirometry }\end{array}$ & $\begin{array}{l}\text { Sensitive } \\
\text { Able to distinguish reliably between } \\
\text { peripheral and proximal airway effects } \\
\text { Does not require any respiratory maneuvers }\end{array}$ & Relatively time-consuming \\
\hline
\end{tabular}

Abbreviations: $\mathrm{FEF}_{25 \%-75 \%}$, forced expiratory flow at $25 \%-75 \%$ of forced vital capacity; IOS, impulse oscillometry; HRCT, high-resolution computed tomography; RV, residual volume; TLC, total lung capacity; FVC, forced vital capacity; CA(NO), alveolar concentration of nitric oxide; dN2, slope of Phase III of the washout curve; CC, closing capacity; R5-R20, resistance from 5 to $20 \mathrm{~Hz}$; FEV , forced expiratory volume in one second; SBW, single-breath washout; MBW, multiple-breath washout; CV, closing volume; Scond, index of conductive airways ventilation heterogeneity; FRC, functional residual capacity.

In a study by Cohen et al, who tested the effect of ciclesonide in mild-to-moderate asthmatics from a functional point of view, improvements were observed in methacholineinduced air trapping on high-resolution CT scan compared with placebo. ${ }^{79}$ Goldin et al directly assessed the difference in efficacy of large versus small particle size ICS, comparing the same drug, ie, beclomethasone, at the same dose but in two different formulations. ${ }^{80}$ After 4 weeks of treatment, they could not detect any difference between the treatment groups based on conventional physiological tests, such as $\mathrm{FEV}_{1}$, or symptoms. Nevertheless, they found greater reduction in air trapping in the hydrofluoroalkane-beclomethasone dipropionate group than in the chlorofluorocarbon-beclomethasone dipropionate group, suggesting an improvement in small airways function. Moreover, after provocation with metacholine, patients treated with hydrofluoroalkane-beclomethasone dipropionate showed a less marked increase in air trapping. ${ }^{80} \mathrm{In}$ another study of patients with mild-to-moderate uncontrolled asthma, 3 months of treatment with traditional or extrafine ICSs resulted in similar improvements in air trapping. ${ }^{81}$ Hydrofluoroalkane-beclomethasone dipropionate has been shown to improve bronchial hyperresponsiveness, ${ }^{30,82}$ impulse oscillometry-measured resistance of the small airways (R5-R20), and reactance area ${ }^{82}$ to a greater extent than chlorofluorocarbon-beclomethasone dipropionate. Similarly, ciclesonide (but not fluticasone) improved R5-R20, reactance area, and distal reactance (X5), ${ }^{78}$ and decreased alveolar nitric oxide levels in mild-to-moderate asthmatics. ${ }^{79}$ In uncontrolled asthmatic patients who received hydrofluoroalkane-beclomethasone dipropionate, improvements in single-breath washout values, ie, closing volume and closing volume/vital capacity, were more noticeable, along with improvement in postbronchodilator $\mathrm{FEF}_{25 \%-75 \%}$ as compared with patients treated with chlorofluorocarbonfluticasone propionate. ${ }^{83}$ Moreover, multiple-breath washout tests in patients with stable asthma and abnormal acinar airways function showed improvements in acinar heterogeneity (Sacin) after switching to hydrofluoroalkane-beclomethasone dipropionate therapy. This improvement correlated with baseline acinar heterogeneity, indicating that patients with more severe inhomogeneity of ventilation benefited most from treatment with the extrafine formulation. ${ }^{84}$ Histological 
Table 3 Changes in small airway inflammation and function as described in studies on extrafine particle sizes of ICS

\begin{tabular}{|c|c|c|c|c|c|}
\hline Authors & Subjects & Treatment & Period & $\begin{array}{l}\text { Assessment } \\
\text { methods }\end{array}$ & Outcomes \\
\hline $\begin{array}{l}\text { Micheletto } \\
\text { et } \mathrm{al}^{30}\end{array}$ & $\begin{array}{l}\text { I5 mild asthma } \\
\text { (steroid-naïve) }\end{array}$ & $\begin{array}{l}\text { CFC-BDP } 1000 \mu g(n=8) \\
\text { versus HFA-BDP } 400 \mu g(n=7)\end{array}$ & 12 weeks & MCh challenge & $\begin{array}{l}\text { Greater increase in } \mathrm{PD}_{20} \mathrm{FEV}_{1} \text { to } \mathrm{MCh} \\
\text { while treated with HFA-BDP. }\end{array}$ \\
\hline $\begin{array}{l}\text { Hauber } \\
\text { et al }{ }^{34}\end{array}$ & $\begin{array}{l}12 \text { mild-to- } \\
\text { moderate asthma }\end{array}$ & HFA-flunisolide $340 \mu \mathrm{g}$ bid & 6 weeks & $\begin{array}{l}\text { Transbronchial } \\
\text { and endobronchial } \\
\text { biopsies }\end{array}$ & $\begin{array}{l}\text { Reduction in eosinophils, IL-5, and } \\
\text { eotaxin, increase in neutrophils, } \\
\text { no change in lymphocytes either in } \\
\text { peripheral or central airways. } \\
\text { Improvement in lung function. }\end{array}$ \\
\hline $\begin{array}{l}\text { Bergeron } \\
\text { et } \mathrm{al}^{76}\end{array}$ & $\begin{array}{l}12 \text { mild-to- } \\
\text { moderate asthma }\end{array}$ & HFA-flunisolide $340 \mu \mathrm{g}$ bid & 6 weeks & $\begin{array}{l}\text { Transbronchial } \\
\text { and endobronchial } \\
\text { biopsies }\end{array}$ & $\begin{array}{l}\text { Decrease in } \alpha \text {-smooth muscle actin area } \\
\text { in peripheral airways, which correlates } \\
\text { with the percentage increase in } \mathrm{FEF}_{25 \%-75 \%} \\
\text { No changes in collagen deposition and } \\
\text { TGF- } \beta \text { expression. }\end{array}$ \\
\hline Ohbayashi ${ }^{77}$ & $\begin{array}{l}74 \text { moderate } \\
\text { stable asthma }\end{array}$ & $\begin{array}{l}\text { FP }(n=37) \text { or BUD }(n=37) \text {, } \\
\text { then switch to HFA-BDP }\end{array}$ & One year & Induced sputum & $\begin{array}{l}\text { Fewer eosinophil-positive patients in } \\
\text { both groups and reduction in sputum } \\
\text { ECP and eotaxin. }\end{array}$ \\
\hline Hoshino $^{78}$ & 30 mild asthma & $\begin{array}{l}\text { Ciclesonide } 200 \mu \mathrm{g} \text { versus } \\
\text { FP } 200 \mu \mathrm{g}\end{array}$ & 8 weeks & $\begin{array}{l}\text { IOS } \\
\text { Induced sputum }\end{array}$ & $\begin{array}{l}\text { Ciclesonide improved resistance of } \\
\text { small airways (R5-R20), distal reactance, } \\
\text { reactance area, decreased late-phase } \\
\text { sputum eosinophils, increased ACT } \\
\text { scores and decreased rescue } \beta_{2} \\
\text { inhalation compared with FP. No changes } \\
\text { in spirometry indices in either group. }\end{array}$ \\
\hline $\begin{array}{l}\text { Cohen } \\
\text { et } \mathrm{al}^{79}\end{array}$ & $\begin{array}{l}16 \text { mild-to- } \\
\text { moderate asthma }\end{array}$ & $\begin{array}{l}\text { Ciclesonide } 320 \mu g(n=9) \\
\text { versus placebo }(n=7)\end{array}$ & 5 weeks & $\begin{array}{l}\text { HRCT } \\
\text { SBNW test } \\
\text { CA(NO) }\end{array}$ & $\begin{array}{l}\text { Improvements in } \mathrm{CA}(\mathrm{NO}) \text { and } \mathrm{MCh}- \\
\text { induced air trapping on } \mathrm{HRCT} \text { as } \\
\text { compared with placebo. } \\
\text { No changes in other small airways } \\
\text { parameters. }\end{array}$ \\
\hline $\begin{array}{l}\text { Goldin } \\
\text { et al }{ }^{80}\end{array}$ & $\begin{array}{l}31 \text { mild-to- } \\
\text { moderate asthma } \\
\text { (steroid-naïe) }\end{array}$ & $\begin{array}{l}\text { CFC-BDP } 100 \mu \mathrm{g} \text { bid versus } \\
\text { HFA-BDP } 100 \mu \mathrm{g} \text { bid }\end{array}$ & 4 weeks & $\mathrm{HRCT}$ & $\begin{array}{l}\text { Greater improvement in air trapping, and } \\
\text { less marked increase in MCh-induced air } \\
\text { trapping in the HFA-BDP group. } \\
\text { Similar improvements in symptoms, } \\
\text { spirometry, and } \mathrm{PC}_{20} \mathrm{MCh} \text {. }\end{array}$ \\
\hline $\begin{array}{l}\text { Tunon-de- } \\
\text { Lara et a }\left.\right|^{81}\end{array}$ & $\begin{array}{l}25 \text { mild-to-moderate } \\
\text { uncontrolled asthma }\end{array}$ & $\begin{array}{l}\text { FP } 250 \mu \mathrm{g} \text { bid versus } \\
\text { HFA-BDP } 200 \mu \mathrm{g} \text { bid }\end{array}$ & 3 months & HRCT & Similar improvements in air trapping. \\
\hline $\begin{array}{l}\text { Yamaguchi } \\
\text { et al }{ }^{82}\end{array}$ & $\begin{array}{l}38 \text { mild-to- } \\
\text { moderate asthma } \\
\text { (steroid-naïv) }\end{array}$ & $\begin{array}{l}\text { HFA-BDP } 200 \mu \mathrm{g} \text { bid }(\mathrm{n}=26) \\
\text { versus CFC-BDP } 400 \mu \mathrm{g} \text { bid } \\
(\mathrm{n}=12)\end{array}$ & 12 weeks & $\begin{array}{l}\text { IOS } \\
\text { MCh challenge }\end{array}$ & $\begin{array}{l}\text { Greater improvements in the resistance } \\
\text { of small airways (R5-R20) and reactance } \\
\text { area (AX) while treated with HFA-BDP. } \\
\text { HFA-BDP attenuated MCh sensitivity. }\end{array}$ \\
\hline $\begin{array}{l}\text { Thongngarm } \\
\text { et al }{ }^{83}\end{array}$ & $\begin{array}{l}30 \text { uncontrolled } \\
\text { asthma }\end{array}$ & $\begin{array}{l}\text { HFA-BDP I } 60 \mu \mathrm{g} \text { bid }(\mathrm{n}=20) \\
\text { versus CFC-FP } 330 \mu \mathrm{g} \\
(\mathrm{n}=10) \text { in addition to the } \\
\text { previous treatment (moderate } \\
\text { to high doses of ICS and other } \\
\text { controller medications) }\end{array}$ & 3 months & SBNW test & $\begin{array}{l}\text { Greater improvements in CV, CV/VC } \\
\text { and postbronchodilator } \mathrm{FEF}_{25 \%-75 \%} \text { while } \\
\text { treated with HFA-BDP. }\end{array}$ \\
\hline $\begin{array}{l}\text { Verbanck } \\
\text { et } \mathrm{al}^{84}\end{array}$ & $\begin{array}{l}30 \text { stable asthma } \\
\text { (wide range of } \\
\text { severity) }\end{array}$ & $\begin{array}{l}\text { BUD, then switch to HFA-BDP } \\
\text { (the same dose for } 6 \text { weeks, } \\
\text { then half dose for another } \\
6 \text { weeks) }\end{array}$ & 12 weeks & MBNW test & $\begin{array}{l}\text { With the switch to HFA-BDP, } \\
\text { improvements in Sacin and RV in the } \\
\text { subgroup of patients with abnormal } \\
\text { baseline Sacin }(n=16) \text { occurred. } \\
\text { Although all patients presented abnormal } \\
\text { baseline Scond, no changes were } \\
\text { observed in this lung zone. }\end{array}$ \\
\hline
\end{tabular}

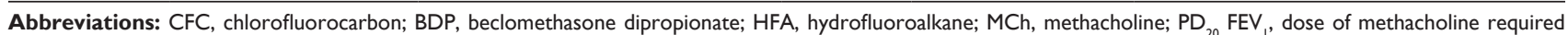
to produce a $20 \%$ fall in the forced expiratory volume in one second; bid, twice a day; IL-5, interleukin-5; FP, fluticasone propionate; HRCT, high-resolution computed tomography scan; $\mathrm{FEF}_{25 \%-75 \%}$, forced expiratory flow at $25 \%-75 \%$ of forced vital capacity; TGF- $\beta$, transforming growth factor beta; BUD, budesonide; ECP, eosinophil cationic protein; IOS, impulse oscillometry; R5-R20, resistance from 5 to $20 \mathrm{~Hz}$; X5, reactance at $5 \mathrm{~Hz}$; AX, reactance area; ACT, Asthma Control Test; SBNW, single-breath nitrogen washout; $\mathrm{CA}(\mathrm{NO})$, alveolar concentration of nitric oxide; $\mathrm{PC}_{20} \mathrm{MCh}$, the provocation concentration of methacholine causing a $20 \%$ reduction in $\mathrm{FEV}$; ICS, inhaled corticosteroids; CV, closing volume; VC, vital capacity; MBNW, multiple-breath nitrogen washout; Sacin, index of acinar airways ventilation heterogeneity; RV, residual volume; Scond, index of conductive airways ventilation heterogeneity. 
Table 4 Clinical outcomes as described by some studies on extrafine particle sizes of ICS

\begin{tabular}{|c|c|c|c|c|c|}
\hline Authors & Subjects & Treatment & Period & Assessment methods & Outcomes \\
\hline $\begin{array}{l}\text { Juniper } \\
\text { et a }{ }^{85}\end{array}$ & 473 stable asthma & $\begin{array}{l}\text { CFC-BDP } 400-1600 \mu \mathrm{g} \\
\text { then switch to half dose } \\
\text { HFA-BDP }(n=354)\end{array}$ & 12 months & $\begin{array}{l}\text { AQLQ } \\
\text { Pulmonary function } \\
\text { tests }\end{array}$ & $\begin{array}{l}\text { Greater improvements in AQLQ scores } \\
\text { while treated with HFA-BDP. } \\
\text { No difference in lung function parameters, } \\
\text { symptoms, or } \beta_{2} \text {-agonist use. }\end{array}$ \\
\hline $\begin{array}{l}\text { Worth } \\
\text { et al }{ }^{86}\end{array}$ & $\begin{array}{l}209 \text { moderate-to- } \\
\text { severe asthma }\end{array}$ & $\begin{array}{l}\text { HFA-BDP } 800 \mu \mathrm{g}(\mathrm{n}=1 \mathrm{I}) \\
\text { versus BUD I600 } \mu \mathrm{g}(\mathrm{n}=98)\end{array}$ & 8 weeks & $\begin{array}{l}\text { Symptoms } \\
\text { Pulmonary function } \\
\text { tests }\end{array}$ & $\begin{array}{l}\text { Greater improvements in the percentage } \\
\text { of days with no experience of shortness of } \\
\text { breath, chest tightness or wheeze, nights } \\
\text { without sleep disturbance, and daily asthma } \\
\text { symptoms while treated with HFA-BDP. } \\
\text { No difference in FEV }, \text { PEF, or } \beta_{2} \text {-agonist use. }\end{array}$ \\
\hline $\begin{array}{l}\text { Tatsis } \\
\text { et } \mathrm{al}^{87}\end{array}$ & $\begin{array}{l}40 \text { moderate } \\
\text { asthma or COPD }\end{array}$ & $\begin{array}{l}\text { BUD } 400 \mu \mathrm{g} \text { bid or FP } 250 \mu \mathrm{g} \\
\text { bid, then switch to HFA-BDP } \\
200 \mu \mathrm{g}(\mathrm{n}=20)\end{array}$ & 8 weeks & $\begin{array}{l}\text { Symptoms } \\
\text { Pulmonary function } \\
\text { tests }\end{array}$ & $\begin{array}{l}\text { Greater improvements in respiratory } \\
\text { symptoms, spirometric values, and } \beta_{2}^{-} \\
\text {agonist use while treated with HFA-BDP. }\end{array}$ \\
\hline $\begin{array}{l}\text { Boulet } \\
\text { et al }{ }^{88}\end{array}$ & $\begin{array}{l}\text { I4I moderate-to- } \\
\text { severe asthma }\end{array}$ & $\begin{array}{l}\text { HFA-BDP } 800 \mu g(n=70) \\
\text { versus CFC-BDP I500 } \mu g \\
(n=7 I)\end{array}$ & 6 months & $\begin{array}{l}\text { Symptoms } \\
\text { Pulmonary function } \\
\text { tests }\end{array}$ & $\begin{array}{l}\text { Onset of the first exacerbation tended to } \\
\text { occur later and asthma symptoms tended } \\
\text { to decrease while treated with HFA-BDP. } \\
\text { Similar pulmonary function. } \\
\text { Similar systemic safety. }\end{array}$ \\
\hline $\begin{array}{l}\text { Barnes } \\
\text { et al }{ }^{89}\end{array}$ & $\begin{array}{l}\text { Large primary } \\
\text { care database } \\
\text { for asthma patients }\end{array}$ & $\begin{array}{l}\text { HFA-BDP }(n=3 \mid 40) \text { versus } \\
\text { CFC-BDP }(n=9162)\end{array}$ & I year & $\begin{array}{l}\text { Asthma control } \\
\text { Exacerbation rate }\end{array}$ & $\begin{array}{l}\text { Patients receiving HFA-BDP are more } \\
\text { likely to achieve asthma control. }\end{array}$ \\
\hline $\begin{array}{l}\text { Huchon } \\
\text { et a }{ }^{90}\end{array}$ & $\begin{array}{l}645 \text { uncontrolled } \\
\text { moderate-to- } \\
\text { severe asthma }\end{array}$ & $\begin{array}{l}\text { HFA-BDP } 200 \mu \mathrm{g} / \text { formoterol } \\
\text { I } 2 \mu \mathrm{g} \text { bid (fixed combination) } \\
\text { versus CFC-BDP } 500 \mu \mathrm{g} \text { bid } \\
\text { and formoterol } 12 \mu \mathrm{g} \text { bid, } \\
\text { or CFC-BDP } 500 \mu \mathrm{g} \text { bid }\end{array}$ & 24 weeks & $\begin{array}{l}\text { Primary outcome: } \\
\text { morning PEF } \\
\text { Secondary outcomes: } \\
\text { pulmonary function test } \\
\text { symptoms, } \\
\text { control, exacerbations }\end{array}$ & $\begin{array}{l}\text { Similar improvements in PEF while using } \\
\text { single inhaler HFA-BDP/formoterol or } \\
\text { while using separate traditional inhalers. } \\
\text { HFA-BDP/formoterol was superior for } \\
\text { asthma control and also with reference to } \\
\text { the percentage of symptom-free days. }\end{array}$ \\
\hline $\begin{array}{l}\text { Müller } \\
\text { et } \mathrm{al}^{9 !}\end{array}$ & $\begin{array}{l}\text { III moderate-to- } \\
\text { severe asthma }\end{array}$ & $\begin{array}{l}\text { HFA-BDP/formoterol } \\
(n=53) \text { versus FP/ } \\
\text { salmeterol }(n=25) \\
\text { or BUD/formoterol }(n=33)\end{array}$ & $\begin{array}{l}\text { Cross- } \\
\text { sectional } \\
\text { real-life } \\
\text { study }\end{array}$ & Asthma control & $\begin{array}{l}\text { Better asthma control total score, daytime } \\
\text { symptom score, and rescue medication use } \\
\text { score; lower mean daily ICS dose while } \\
\text { treated with HFA-BDP/formoterol. }\end{array}$ \\
\hline
\end{tabular}

Abbreviations: CFC, chlorofluorocarbon; BDP, beclomethasone dipropionate; HFA, hydrofluoroalkane; AQLQ, Asthma Quality of Life Questionnaire; BUD, budesonide; $\mathrm{FEV}_{1}$, forced expiratory volume in one second; PEF, peak expiratory flow; COPD, chronic obstructive pulmonary disease; bid, twice a day; FP, fluticasone propionate; ICS, inhaled corticosteroids.

and functional studies using extrafine ICS are summarized in Table 3, while the outcomes of clinical studies are reviewed in Table 4.

\section{Conclusion}

Small airways disease plays an important role in the pathogenesis of asthma, but the assessment of small airways impairment is not easy in everyday clinical practice. The small airways can be examined by several invasive and noninvasive methods, most of which can at present be used only in experimental settings. Inhalers that provide extrafine particle sizes of ICS may enable sufficient drug deposition in the peripheral airways. Many studies have shown the beneficial effects of extrafine ICS on inflammation in asthma, including dysfunction in both the central and distal airways, and there are data on some asthma phenotypes in which the small airways seem to be affected more than in other phenotypes, including nocturnal asthma, severe steroid-dependent or difficult-to-treat asthma, asthma complicated by smoking, elderly asthmatic patients and those with fixed airflow obstruction, and asthmatic children. The randomized clinical trials reported to date show that the extrafine and nonextrafine ICS formulations have similar efficacy in terms of primary endpoints; however, there are certain clinically important endpoints for which the extrafine formulations show additional benefits.

\section{Disclosure}

The authors report no conflicts of interest in this work.

\section{References}

1. Lötvall J, Akdis CA, Bacharier LB, et al. Asthma endotypes: a new approach to classification of disease entities within the asthma syndrome. J Allergy Clin Immunol. 2011;127:355-360.

2. Wenzel S. Severe asthma: from characteristics to phenotypes to endotypes. Clin Exp Allergy. 2012;42:650-658.

3. Global Strategy for Asthma Management and Prevention, Global Initiative for Asthma, 2011. Available from: http://www.ginasthma.org/. Accessed May 12, 2013. 
4. Almind M, Viskum K, Evald T, et al. A seven-year follow-up study of 343 adults with bronchial asthma. Dan Med Bull. 1992;39:561-565.

5. Martin RJ. Small airway and alveolar tissue changes in nocturnal asthma. Am J Respir Crit Care Med. 1998;157:188-190.

6. Bateman ED, Boushey HA, Bousquet J, et al. Can guideline-defined asthma control be achieved? The Gaining Optimal Asthma ControL study. Am J Respir Crit Care Med. 2004;170:836-844.

7. Lange P, Parner J, Vestbo J, et al. A 15 -year follow-up study of ventilatory function in adults with asthma. N Engl J Med. 1998;339:1194-1200.

8. van Veen IH, Ten Brinke A, Sterk PJ, et al. Exhaled nitric oxide predicts lung function decline in difficult-to-treat asthma. Eur Respir J. 2008;32:344-349.

9. Stempel DA, McLaughin TP, Stanford RH, et al. Patterns of asthma control: a 3-year analysis of patient claims. J Allergy Clin Immunol. 2005;115:935-939.

10. Peters SP, Jones CA, Haselkorn T, et al. Real-world Evaluation of Asthma Control and Treatment (REACT): findings from a national Web-based survey. J Allergy Clin Immunol. 2007;119(6):1454-1461.

11. Cazzoletti L, Marcon A, Janson C, et al. Asthma control in Europe: a real-world evaluation based on an international population-based study. J Allergy Clin Immunol. 2007;120:1360-1367.

12. Hamid Q, Song Y, Kotsimbos TC, et al. Inflammation of small airways in asthma. J Allergy Clin Immunol. 1997;100:44-51.

13. Takeda T, Oga T, Niimi A, et al. Relationship between small airway function and health status, dyspnea, and disease control in asthma. Respiration. 2010;80:120-126.

14. Kraft M, Djukanovic R, Wilson S, et al. Alveolar tissue inflammation in asthma. Am J Respir Crit Care Med. 1996;154:1505-1510.

15. de Magalhães Simões S, dos Santos MA, da Silva Oliveira M, et al. Inflammatory cell mapping of the respiratory tract in fatal asthma. Clin Exp Allergy. 2005;35:602-611.

16. Weibel ER. Morphometry of the Human Lung. New York, NY: Academic Press; 1963

17. Yanai M, Sekizawa K, Ohrui T, et al. Site of airway obstruction in pulmonary disease: direct measurement of intrabronchial pressure. J Appl Physiol. 1992;72:1016-1023.

18. Kuwano K, Bosken CH, Pare PD, et al. Small airways dimensions in asthma and in chronic obstructive pulmonary disease. Am Rev Respir Dis. 1993;148:1220-1225.

19. Wagner EM, Liu MC, Weinmann GG, et al. Peripheral lung resistance in normal and asthmatic subjects. Am Rev Respir Dis. 1990;141:584-588.

20. Aikawa T, Shimura S, Sasaki H, et al. Marked goblet cell hyperplasia with mucus accumulation in the airways of patients who died of severe acute asthma attack. Chest. 1992;101:916-921.

21. Kuyper LM, Pare PD, Hogg JC, et al. Characterization of airway plugging in fatal asthma. Am J Med. 2003;115:6-11.

22. Faul JL, Tormey VJ, Leonard C, et al. Lung immunopathology in cases of sudden asthma death. Eur Respir J. 1997;10:301-307.

23. James AL, Pare PD, Hogg JC. The mechanics of airway narrowing in asthma. Am Rev Respir Dis. 1989;139:242-246.

24. Wiggs BR, Bosken C, Pare PD, et al. A model of airway narrowing in asthma and in chronic obstructive pulmonary disease. Am Rev Respir Dis. 1992;145:1251-1258.

25. Ebina M, Takahashi T, Chiba T, et al. Cellular hypertrophy and hyperplasia of airway smooth muscles underlying bronchial asthma. A 3-D morphometric study. Am Rev Respir Dis. 1993;148:720-726.

26. Carroll N, Elliot J, Morton A, et al. The structure of large and small airways in nonfatal and fatal asthma. Am Rev Respir Dis. 1993;147:405-410.

27. Dolhnikoff M, da Silva LF, de Araujo BB, et al. The outer wall of small airways is a major site of remodeling in fatal asthma. J Allergy Clin Immunol. 2009;123:1090-1097.

28. Mauad T, Silva LF, Santos MA, et al. Abnormal alveolar attachments with decreased elastic fiber content in distal lung in fatal asthma. Am J Respir Crit Care Med. 2004;170:857-862.

29. Balzar S, Chu HW, Strand M, et al. Relationship of small airway chymase-positive mast cells and lung function in severe asthma. Am J Respir Crit Care Med. 2005;171:431-439.
30. Micheletto C, Guerriero M, Tognella S, et al. Effects of HFA- and CFCbeclomethasone dipropionate on the bronchial response to methacholine (MCh) in mild asthma. Respir Med. 2005;99:850-855.

31. Minshall EM, Hogg JC, Hamid QA. Cytokine mRNA expression in asthma is not restricted to the large airways. J Allergy Clin Immunol. 1998;101:386-390.

32. Taha RA, Minshall EM, Miotto D, et al. Eotaxin and monocyte chemotactic protein-4 mRNA expression in small airways of asthmatic and nonasthmatic individuals. J Allergy Clin Immunol. 1999;103: 476-483.

33. Booth H, Richmond I, Ward C, et al. Effect of high dose inhaled fluticasone propionate on airway inflammation in asthma. Am J Respir Crit Care Med. 1995;152:45-52.

34. Hauber HP, Gotfried M, Newman K, et al. Effect of HFA-flunisolide on peripheral lung inflammation in asthma. J Allergy Clin Immunol. 2003;112:58-63.

35. Wenzel SE, Szefler SJ, Leung DY, et al. Bronchoscopic evaluation of severe asthma: persistent inflammation associated with high dose glucocorticoids. Am J Respir Crit Care Med. 1997;156:737-743.

36. Andersson CK, Bergqvist A, Mori M, et al. Mast cell-associated alveolar inflammation in patients with atopic uncontrolled asthma. JAllergy Clin Immunol. 2011;127:905-912, e901-e907.

37. Contoli M, Kraft M, Hamid Q, et al. Do small airway abnormalities characterize asthma phenotypes? In search of proof. Clin Exp Allergy. 2012;42:1150-1160.

38. Cassino C, Berger KI, Goldring RM, et al. Duration of asthma and physiologic outcomes in elderly nonsmokers. Am J Respir Crit Care Med. 2000;162(4 Pt 1):1423-1428.

39. Broekema M, ten Hacken NH, Volbeda F, et al. Airway epithelial changes in smokers but not in ex-smokers with asthma. Am J Respir Crit Care Med. 2009;180:1170-1178.

40. Chalmers GW, Macleod KJ, Little SA, et al. Influence of cigarette smoking on inhaled corticosteroid treatment in mild asthma. Thorax. 2002;57:226-230.

41. Chaudhuri R, Livingston E, McMahon AD, et al. Cigarette smoking impairs the therapeutic response to oral corticosteroids in chronic asthma. Am J Respir Crit Care Med. 2003;168:1308-1311.

42. Macklem PT, Mead J. Resistance of central and peripheral airways measured by a retrograde catheter. J Appl Physiol. 1967;22:395-401.

43. Sorkness RL, Bleecker ER, Busse WW, et al. Lung function in adults with stable but severe asthma: air trapping and incomplete reversal of obstruction with bronchodilation. J Appl Physiol. 2008;104: 394-403.

44. Sutherland ER, Martin RJ, Bowler RP, et al. Physiologic correlates of distal lung inflammation in asthma. J Allergy Clin Immunol. 2004;113: 1046-1050.

45. Bourdin A, Paganin F, Prefaut C, et al. Nitrogen washout slope in poorly controlled asthma. Allergy. 2006;61:85-89.

46. Gibbons WJ, Sharma A, Lougheed D, et al. Detection of excessive bronchoconstriction in asthma. Am J Respir Crit Care Med. 1996;153: 582-589.

47. Yu J, Yoo Y, Kim DK, et al. The relationship between delta-forced vital capacity (percent fall in forced vital capacity at the PC20 dose of methacholine) and the maximal airway response in patients who have mild asthma. Allergy Asthma Proc. 2005;26:366-372.

48. Schleich FN, Seidel L, Sele J, et al. Exhaled nitric oxide thresholds associated with a sputum eosinophil count $\geq 3 \%$ in a cohort of unselected patients with asthma. Thorax. 2010;65:1039-1044.

49. Verbanck S, Schuermans D, Vincken W. Inflammation and airway function in the lung periphery of patients with stable asthma. J Allergy Clin Immunol. 2010;125:611-616.

50. van Veen IH, Sterk PJ, Schot R, et al. Alveolar nitric oxide versus measures of peripheral airway dysfunction in severe asthma. Eur Respir J. 2006;27:951-956.

51. Berry M, Hargadon B, Morgan A, et al. Alveolar nitric oxide in adults with asthma: evidence of distal lung inflammation in refractory asthma. Eur Respir J. 2005;25:986-991. 
52. Williamson PA, Clearie K, Menzies D, et al. Assessment of smallairways disease using alveolar nitric oxide and impulse oscillometry in asthma and COPD. Lung. 2011;189:121-129.

53. Beigelman-Aubry C, Capderou A, Grenier PA, et al. Mild intermittent asthma: CT assessment of bronchial cross-sectional area and lung attenuation at controlled lung volume. Radiology. 2002;223:181-187.

54. Müller NL. Computed tomography and magnetic resonance imaging: past, present and future. Eur Respir J Suppl. 2002;35:3s-12s.

55. Busacker A, Newell JD Jr, Keefe T, et al. A multivariate analysis of risk factors for the air-trapping asthmatic phenotype as measured by quantitative CT analysis. Chest. 2009;135:48-56.

56. Mitsunobu F, Ashida K, Hosaki Y, et al. Decreased computed tomographic lung density during exacerbation of asthma. Eur Respir $J$ 2003;22:106-112.

57. Ueda T, Niimi A, Matsumoto H, et al. Role of small airways in asthma: investigation using high-resolution computed tomography. J Allergy Clin Immunol. 2006;118:1019-1025.

58. Zeidler MR, Kleerup EC, Goldin JG, et al. Montelukast improves regional air-trapping due to small airways obstruction in asthma. Eur Respir J. 2006;27:307-315.

59. Verbanck S, Schuermans D, Meysman M, et al. Noninvasive assessment of airway alterations in smokers: the small airways revisited. Am J Respir Crit Care Med. 2004;170:414-419.

60. Robinson PD, Latzin P, Verbanck S, et al. Consensus statement for inert gas washout measurement using multiple- and single- breath tests. Eur Respir J. 2013;41:507-522.

61. King GG. Cutting edge technologies in respiratory research: lung function testing. Respirology. 2011;16:883-890.

62. McFadden ER Jr, Kiker R, Holmes B, et al. Small airway disease An assessment of the tests of peripheral airway function. Am J Med. 1974;57:171-182.

63. in't Veen JC, Beekman AJ, Bel EH, et al. Recurrent exacerbations in severe asthma are associated with enhanced airway closure during stable episodes. Am J Respir Crit Care Med. 2000;161:1902-1906.

64. Verbanck S, Schuermans D, Noppen M, et al. Evidence of acinar airway involvement in asthma. Am J Respir Crit Care Med. 1999;159(5 Pt 1): 1545-1550.

65. Downie SR, Salome CM, Verbanck S, et al. Ventilation heterogeneity is a major determinant of airway hyperresponsiveness in asthma, independent of airway inflammation. Thorax. 2007;62:684-689.

66. Goldman MD, Saadeh C, Ross D. Clinical applications of forced oscillation to assess peripheral airway function. Respir Physiol Neurobiol. 2005;148:179-194.

67. Oppenheimer BW, Goldring RM, Herberg ME, et al. Distal airway function in symptomatic subjects with normal spirometry following World Trade Center dust exposure. Chest. 2007;132:1275-1282.

68. Nieto A, Pamies R, Oliver F, et al. Montelukast improves pulmonary function measured by impulse oscillometry in children with asthma (MIO study). Respir Med. 2006;100:1180-1185.

69. Borrill ZL, Houghton CM, Tal-Singer R, et al. The use of plethysmography and oscillometry to compare long-acting bronchodilators in patients with COPD. Br J Clin Pharmacol. 2008;65:244-252.

70. Evans TM, Rundell KW, Beck KC, et al. Airway narrowing measured by spirometry and impulse oscillometry following room temperature and cold temperature exercise. Chest. 2005;128:2412-2419.

71. Glover W, Chan HK, Eberl S, et al. Effect of particle size of dry powder mannitol on the lung deposition in healthy volunteers. Int J Pharm. 2008;349:314-322.

72. Leach CL, Davidson PJ, Hasselquist BE, et al. Lung deposition of hydrofluoroalkane-134a beclomethasone is greater than that of chlorofluorocarbon fluticasone and chlorofluorocarbon beclomethasone: a cross-over study in healthy volunteers. Chest. 2002;122:510-516.

73. Leach C, Colice GL, Luskin A. Particle size of inhaled corticosteroids: does it matter? J Allergy Clin Immunol. 2009;124(Suppl 6):S88-S93.
74. Häussermann S, Acerbi D, Brand P, et al. Lung deposition of formoterol HFA (Atimos/Forair) in healthy volunteers, asthmatic and COPD patients. J Aerosol Med. 2007;20:331-341.

75. Leach CL, Davidson PJ, Hasselquist BE, et al. Influence of particle size and patient dosing technique on lung deposition of HFAbeclomethasone from a metered dose inhaler. J Aerosol Med. 2005;18: 379-385.

76. Bergeron C, Hauber HP, Gotfried M, et al. Evidence of remodeling in peripheral airways of patients with mild to moderate asthma: effect of hydrofluoroalkane-flunisolide. J Allergy Clin Immunol. 2005;116:983-989.

77. Ohbayashi H. One-year evaluation of the preventative effect of hydrofluoroalkane-beclomethasone dipropionate on eosinophilic inflammation of asthmatic peripheral airways. Respiration. 2007;74:146-153.

78. Hoshino M. Comparison of effectiveness in ciclesonide and fluticasone propionate on small airway function in mild asthma. Allergol Int. 2010;59:59-66.

79. Cohen J, Douma WR, ten Hacken NH, et al. Ciclesonide improves measures of small airway involvement in asthma. Eur Respir J. 2008;31:1213-1220.

80. Goldin JG, Tashkin DP, Kleerup EC, et al. Comparative effects of hydrofluoroalkane and chlorofluorocarbon beclomethasone dipropionate inhalation on small airways: assessment with functional helical thin-section computed tomography. J Allergy Clin Immunol. 1999; 104:S258-S267.

81. Tunon-de-Lara JM, Laurent F, Giraud V, et al. Air trapping in mild and moderate asthma: effect of inhaled corticosteroids. J Allergy Clin Immunol. 2007;119:583-590.

82. Yamaguchi M, Niimi A, Ueda T, et al. Effect of inhaled corticosteroids on small airways in asthma: investigation using impulse oscillometry. Pulm Pharmacol Ther. 2009;22:326-332.

83. Thongngarm T, Silkoff PE, Kossack WS, et al. Hydrofluoroalkane-134A beclomethasone or chlorofluorocarbon fluticasone: effect on small airways in poorly controlled asthma. J Asthma. 2005;42:257-263.

84. Verbanck S, Schuermans D, Paiva M, et al. The functional benefit of anti-inflammatory aerosols in the lung periphery. J Allergy Clin Immunol. 2006;118:340-346.

85. Juniper EF, Price DB, Stampone PA, et al. Clinically important improvements in asthma-specific quality of life, but no difference in conventional clinical indexes in patients changed from conventional beclomethasone dipropionate to approximately half the dose of extrafine beclomethasone dipropionate. Chest. 2002;121:1824-1832.

86. Worth H, Muir JF, Pieters WR. Comparison of hydrofluoroalkanebeclomethasone dipropionate Autohaler with budesonide Turbuhaler in asthma control. Respiration. 2001;68:517-526.

87. Tatsis G, Kotsifas K, Filaditaki V, et al. Efficacy of beclomethasone dipropionate HFA 200 microg once daily in chronic obstructive pulmonary disease and bronchial asthma. J Int Med Res. 2007;35:361-373.

88. Boulet LP, Cartier A, Ernst P, et al. Safety and efficacy of HFA-134a beclomethasone dipropionate extrafine aerosol over six months. Can Respir J. 2004;11:123-130.

89. Barnes N, Price D, Colice G, et al. Asthma control with extrafine-particle hydrofluoroalkane-beclometasone vs large-particle chlorofluorocarbonbeclometasone: a real-world observational study. Clin Exp Allergy. 2011;41:1521-1532.

90. Huchon G, Magnussen H, Chuchalin A, et al. Lung function and asthma control with beclomethasone and formoterol in a single inhaler. Respir Med. 2009;103:41-49.

91. Müller V, Gálffy G, Eszes N, et al. Asthma control in patients receiving inhaled corticosteroid and long-acting beta2-agonist fixed combinations. A real-life study comparing dry powder inhalers and a pressurized metered dose inhaler extrafine formulation. BMC Pulm Med. 2011;11:40. 
Journal of Asthma and Allergy

Dovepress

\section{Publish your work in this journal}

The Journal of Asthma and Allergy is an international, peer-reviewed open-access journal publishing original research, reports, editorials and commentaries on the following topics: Asthma; Pulmonary physiology; Asthma related clinical health; Clinical immunology and the immunological basis of disease; Pharmacological interventions and

new therapies. Issues of patient safety and quality of care will also be considered. The manuscript management system is completely online and includes a very quick and fair peer-review system, which is all easy to use. Visit http://www.dovepress.com/testimonials.php to read real quotes from published authors.

Submit your manuscript here: http://www.dovepress.com/journal-of-asthma-and-allergy-journal 